www.nature.com/pj

\title{
Evaluation of the stimulus response of hydroxyapatite/ calcium alginate composite gels
}

\author{
Sachiko Obara ${ }^{1}$, Takeshi Yamauchi ${ }^{1,2}$ and Norio Tsubokawa ${ }^{1,2}$ \\ Stimuli-responsive gels have been actively studied and applied to a variety of devices such as drug carriers, artificial muscles \\ and actuators. In this research study, calcium alginate gels containing hydroxyapatite were prepared in one step by adding a \\ diammonium hydrogenphosphate-1\% alginate solution to a calcium chloride solution and evaluated for $\mathrm{pH}$ dependence and \\ electrochemical properties as stimuli-responsive gels. When the composite gel was immersed in a solution of pH 2-10 or \\ subjected to an applied voltage, the composite gel with a high content of hydroxyapatite tended to maintain its volume. The \\ composite gels immersed in a pH indicator solution changed color with an applied voltage. As a result, it was revealed that \\ alteration of the $\mathrm{pH}$ of composite gels occurred by electro-osmosis and electrophoresis. Swelling and shrinking of the composite \\ gels were controlled by the external stimuli of $\mathrm{pH}$, voltage and the content of hydroxyapatite; therefore, it is proposed that \\ composite gels would be good bone-filling material having the function of drug carriers.
}

Polymer Journal (2010) 42, 161-166; doi:10.1038/pj.2009.310; published online 6 January 2010

Keywords: calcium alginate; electrochemical property; gel; hydroxyapatite; ph dependence; stimulus response

\section{INTRODUCTION}

Stimuli-responsive gels are known to change their shape, solubility and degree of ionization because of physical and chemical external stimuli. ${ }^{1-3}$ Physical stimuli include temperature, electric field, solvent, light, pressure, sound and magnetic field. ${ }^{4}$ Chemical or biochemical stimuli include $\mathrm{pH}$, ions, and so on. ${ }^{4}$ Ionic gels are stimuli-responsive gels that change volume because of $\mathrm{pH}$ or electrical stimulus. These properties are used for a variety of devices such as drug carriers, artificial muscles and actuators.

Alginate gel, an ionic gel, ${ }^{5-7}$ has been widely used in drug carriers and tissue engineering. ${ }^{8,9}$ Alginates are polysaccharides extracted from seaweed and electrolytes that have carboxyl groups. They are composed of two monomers, $\beta$-D-mannuronate and $\alpha$-L-guluronate, ${ }^{10,11}$ which are known to form gels in the presence of bivalent cations such as $\mathrm{Ca}^{2+} \cdot{ }^{10-12}$

Hydroxyapatite is generated from calcium chloride $\left(\mathrm{CaCl}_{2}\right)$ and diammonium hydrogenphosphate $\left(\left(\mathrm{NH}_{4}\right)_{2} \mathrm{HPO}_{4}\right) \cdot{ }^{13}$ Hydroxyapatite, which has a good biocompatibility and a high biological affinity, is used as bone-filling material for treating bone defects caused by disease or injury. This material promotes the reproduction of new bone by injection into bone cavities. Even though hydroxyapatite has been used as a bone-filling material, it requires a long time to be replaced with host bone after implantation. ${ }^{14-16}$ Composite materials composed of hydroxyapatite and hydrogels would be suitable to fill large bone defects and would be easily absorbed by the patient's body.

Composite gels were prepared from hydroxyapatite and calcium alginate gels. The preparation of both hydroxyapatite and calcium alginate uses $\mathrm{CaCl}_{2}$, and therefore hydroxyapatite/calcium alginate composite gels were prepared in one step. This composite gel could be applied as bone-filling material and would also have the function of a drug carrier.

Bone is a living tissue that is continually adapting to its biological environment through continuous formation and resorption. ${ }^{17}$ It is said that bone remodeling, a dynamic process, occurs in both cortical and trabecular (or cancellous) bone, allowing a rapid response to changes in circulating calcium levels. ${ }^{18-19}$ Bone formation occurs when calcium is incorporated into the organic bone matrix secreted from osteoblasts. ${ }^{20}$ Bone resorption occurs when the organic bone matrix is decomposed by enzymes and by $\mathrm{H}^{+}$ions from osteoclasts. ${ }^{20}$ In particular, the $\mathrm{pH}$ of resorbed lacunae after bone resorption decreases to $3-4 .^{21}$

In this study, the stimuli-responsive characteristics of hydroxyapatite/calcium alginate composite gels were evaluated. As described above, the $\mathrm{pH}$ is changed in in vivo bone during bone remodeling. Therefore, the volume changes with $\mathrm{pH}$ of the composite gels were determined to apply them as drug carriers. In addition, the $\mathrm{pH}$ change is related to the movement of ions. Consequently, voltages were applied to the composite gels to move ions.

\section{EXPERIMENTAL PROCEDURE}

Materials and reagents

Calcium chloride ( $\mathrm{FW}=110.98),\left(\mathrm{NH}_{4}\right)_{2} \mathrm{HPO}_{4}(\mathrm{FW}=132.06), 0.01 \mathrm{м}$ hydrochloric acid $(\mathrm{N} / 100)(\mathrm{HCl}, 0.04 \% \mathrm{HCl}$ in water $), 0.01 \mathrm{M}$ sodium hydroxide 
solution $(\mathrm{N} / 100)\left(\mathrm{NaOH}, 0.04 \% \mathrm{NaOH}\right.$ in water), thymol blue $\left(\mathrm{C}_{27} \mathrm{H}_{30} \mathrm{O}_{5} \mathrm{~S}\right)$ $(\mathrm{FW}=466.59)$, methyl red $\left(\mathrm{C}_{15} \mathrm{H}_{15} \mathrm{~N}_{3} \mathrm{O}_{2}\right)(\mathrm{FW}=269.3)$, bromothymol blue $\left(\mathrm{C}_{27} \mathrm{H}_{28} \mathrm{Br}_{2} \mathrm{O}_{5} \mathrm{~S}\right)(\mathrm{FW}=624.38)$ and phenolphthalein $\left(\mathrm{C}_{20} \mathrm{H}_{14} \mathrm{O}_{4}\right)(\mathrm{FW}=318.32)$ were obtained from Kanto Chemical (Tokyo, Japan) and used without further purification. Sodium alginate $(300 \mathrm{cps})$ was obtained from Nacalai Tesque (Kyoto, Japan) and used without further purification.

\section{Preparation of hydroxyapatite/calcium alginate composite gel}

Drops of $\left(\mathrm{NH}_{4}\right)_{2} \mathrm{HPO}_{4}(120 \mathrm{~mm}$ and $480 \mathrm{~mm})-1 \%$ sodium alginate aqueous solution were added to $\mathrm{CaCl}_{2}(250 \mathrm{~mm}$ and $1000 \mathrm{~mm}$ ) aqueous solution, which was immersed in $\mathrm{CaCl}_{2}$ aqueous solution until equilibrium. Then, we obtained two types of composite gel: $250 \mathrm{~mm} \mathrm{CaCl} 2-120 \mathrm{mM}\left(\mathrm{NH}_{4}\right)_{2} \mathrm{HPO}_{4}-1 \%$ calcium alginate composite gels and $1000 \mathrm{~mm} \mathrm{CaCl}_{2}-480 \mathrm{~mm} \quad\left(\mathrm{NH}_{4}\right)_{2} \mathrm{HPO}_{4}-1 \%$ calcium alginate composite gels. In addition, calcium alginate gels were prepared from $1 \%$ sodium alginate aqueous solution and $100 \mathrm{~mm} \mathrm{CaCl}_{2}$ aqueous solution. All the gels were immersed in distilled water, which was changed three times. The content of hydroxyapatite in the composite gels was measured with a thermogravimetrical analyzer.

\section{Observation of $\mathrm{pH}$ dependence of composite gels}

Composite gels and calcium alginate gels were immersed in distilled water. The gels were observed at 30-min intervals using a stereomicroscope (Shimadzu Manufacturing, Kyoto, Japan, STZ-168-BL/TL). The volume alteration ratio was calculated from the diameters of the composite gel and calcium alginate gel. The experiment was carried out with three types of gels ( $1 \%$ calcium alginate, $250 \mathrm{~mm} \mathrm{CaCl} 2-120 \mathrm{~mm}\left(\mathrm{NH}_{4}\right)_{2} \mathrm{HPO}_{4}-1 \%$ calcium alginate and $1000 \mathrm{~mm} \mathrm{CaCl}_{2}-480 \mathrm{~mm} \quad\left(\mathrm{NH}_{4}\right)_{2} \mathrm{HPO}_{4}-1 \%$ calcium alginate) and using $0.01 \mathrm{M} \mathrm{HCl}$ or $0.01 \mathrm{M} \mathrm{NaOH}$ solutions instead of distilled water.

\section{Observation of the electrochemical properties of composite gels}

Various voltages were applied to the composite gels with a Pt mesh anode and a Pt rod cathode on the bottle of distilled water or $100 \mathrm{mM} \mathrm{CaCl}_{2}$ solution. Then, the gels were observed at 1-min intervals using a stereomicroscope (Shimadzu Manufacturing, STZ-168-BL/TL). The volume alteration ratio was calculated from the diameters of the composite gel and calcium alginate gel.

\section{Observation of the $\mathrm{pH}$ dependence of the composite gels by electrical stimulus}

Universal $\mathrm{pH}$ indicator solution was prepared by combining four types of dyes. ${ }^{22,23}$ Thymol blue $0.005 \mathrm{~g}$, methyl red $0.0125 \mathrm{~g}$, bromothymol blue $0.05 \mathrm{~g}$ and phenolphthalein $0.10 \mathrm{~g}$ were dissolved in $100 \mathrm{ml}$ of ethanol, neutralized with $0.1 \mathrm{M} \mathrm{NaOH}$ and diluted to a total volume of $200 \mathrm{ml}$ with distilled water.

Composite gels and calcium alginate gels were immersed in the $\mathrm{pH}$ indicator solution for 1 day. Then, a voltage was applied to the composite gels.

\section{RESULTS AND DISCUSSION}

Preparation of hydroxyapatite/calcium alginate composite gel The composite gels were prepared with $\mathrm{CaCl}_{2}$ solution and $\left(\mathrm{NH}_{4}\right)_{2} \mathrm{HPO}_{4}$-sodium alginate solution. The composite gels were white in color and spherical in shape. Figure 1 shows cross-sections of $1 \%$ alginate gel and $1000 \mathrm{~mm} \mathrm{CaCl}_{2}-480 \mathrm{~mm}\left(\mathrm{NH}_{4}\right)_{2} \mathrm{HPO}_{4} \quad 1 \%$ alginate gel. The cross-section of the $1 \%$ alginate gel was clear. In case of $1000 \mathrm{mM} \mathrm{CaCl}_{2}-480 \mathrm{~mm}\left(\mathrm{NH}_{4}\right)_{2} \mathrm{HPO}_{4} 1 \%$ alginate gel, the center of the cross-section was clear, and the exterior of the cross-section was white. It is considered that hydroxyapatite crystallizes at the exterior of the composite gels.

The crystallization of white hydroxyapatite in the composite gel was confirmed by X-ray diffraction and infrared spectroscopy. As a result of X-ray diffraction, the hydroxyapatite phases in the composite gels were confirmed from the peaks at $2 \theta=25.9^{\circ}(002), 31.8^{\circ}(211), 32.2^{\circ}$ (112) and $32.9^{\circ}(300) .^{24}$ According to the results of infrared spectroscopy, absorption between 1100 and $1000 \mathrm{~cm}^{-1}$ corresponding to $\mathrm{PO}_{4}{ }^{3-}$ or $\mathrm{HPO}_{4}{ }^{2-}$ in the composite gels was observed. These results indicated that hydroxyapatite was successfully grown with $\mathrm{CaCl}_{2}$ and $\left(\mathrm{NH}_{4}\right)_{2} \mathrm{HPO}_{4}$ in calcium alginate gel. The content of hydroxyapatite in the composite gel was measured with thermogravimetrical analyzer, and 49.9 and $61.8 \%$ hydroxyapatite was contained in the composite gel prepared from $250 \mathrm{~mm} \mathrm{CaCl}_{2}$ and $120 \mathrm{~mm}\left(\mathrm{NH}_{4}\right)_{2} \mathrm{HPO}_{4}$, and $1000 \mathrm{mM} \mathrm{CaCl}_{2}$ and $480 \mathrm{~mm}\left(\mathrm{NH}_{4}\right)_{2} \mathrm{HPO}_{4}$, respectively. ${ }^{25}$ The content of hydroxyapatite in the gel was significantly related to the concentration and ratio of $\mathrm{CaCl}_{2}$ and $\left(\mathrm{NH}_{4}\right)_{2} \mathrm{HPO}_{4}$

\section{Observation of the $\mathrm{pH}$ dependence of the composite gels}

Stimulus response by $\mathrm{pH}$ was determined by immersing the composite gels in solutions of distilled water, $0.01 \mathrm{M} \mathrm{HCl}(\mathrm{pH} 2)$ and $0.01 \mathrm{M}$ $\mathrm{NaOH}$ ( $\mathrm{pH}$ 10) (Figure 2). The gel volume was not changed by water immersion. However, the volume of the gel decreased after immersion in $\mathrm{pH} 2$ solution. In contrast, the volume of the gel increased in $\mathrm{pH} 10$ solution.

Figure 3 shows the volume alteration ratio of composite gels with $\mathrm{pH}$ over time. The volume of the gels before immersion into solutions of $\mathrm{pH} 2$ and 10 was defined as $100 \%$, and the volume alteration ratio of composite gels was calculated. The alginate gel and the hydroxyapatite/calcium alginate gel decreased in volume to about $30 \%$ after $3 \mathrm{~h}$ in an acidic solution of $\mathrm{pH} 2$. The gels containing more hydroxyapatite decreased in volume more slowly than the gels containing less hydroxyapatite. All gels increased in volume in the alkaline solution of $\mathrm{pH} 10$. Calcium alginate gels were 500\% larger than the gels before immersion into the alkaline solution. The gels containing more hydroxyapatite showed little change in the alkaline solution. The gel became difficult to stretch after hydroxyapatite was generated.

Figure 4 shows the $\mathrm{pH}$ dependence of the $1000 \mathrm{~mm} \mathrm{CaCl}_{2}-480 \mathrm{~mm}$ $\left(\mathrm{NH}_{4}\right)_{2} \mathrm{HPO}_{4} 1 \%$ alginate gel after immersion for $2 \mathrm{~h}$. The volume of the composite gel was constant between $\mathrm{pH} 5$ and 10. The volume of the composite gel decreased below $\mathrm{pH} 3$.
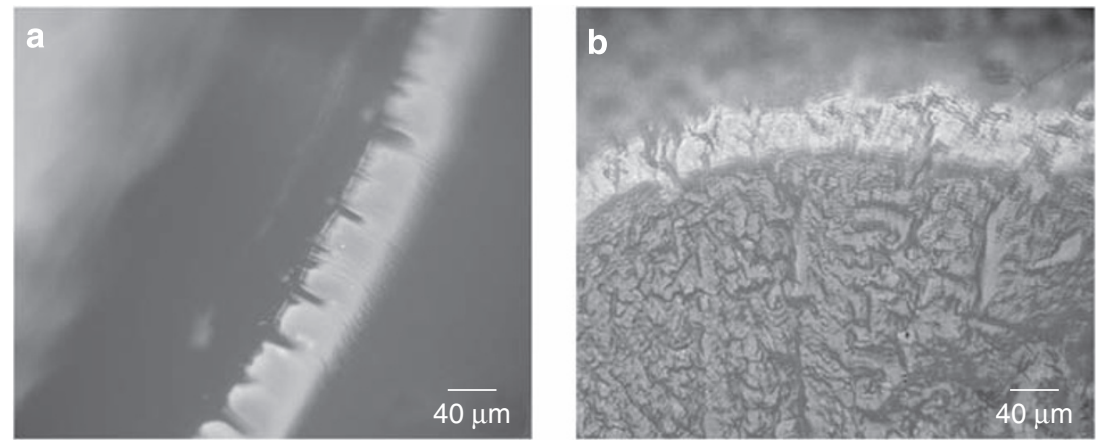

Figure 1 Cross-section of (a) $1 \%$ alginate gel and (b) $1000 \mathrm{~mm} \mathrm{CaCl} 2-480 \mathrm{~mm}\left(\mathrm{NH}_{4}\right)_{2} \mathrm{HPO}_{4} 1 \%$ alginate gel. 


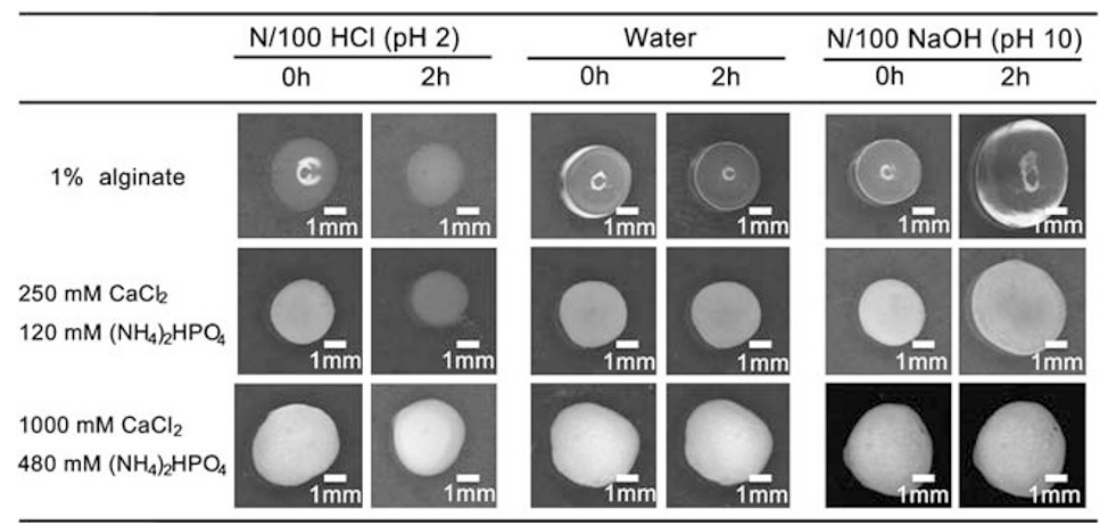

Figure 2 Shrinking and swelling of composite gels due to $\mathrm{pH}$.
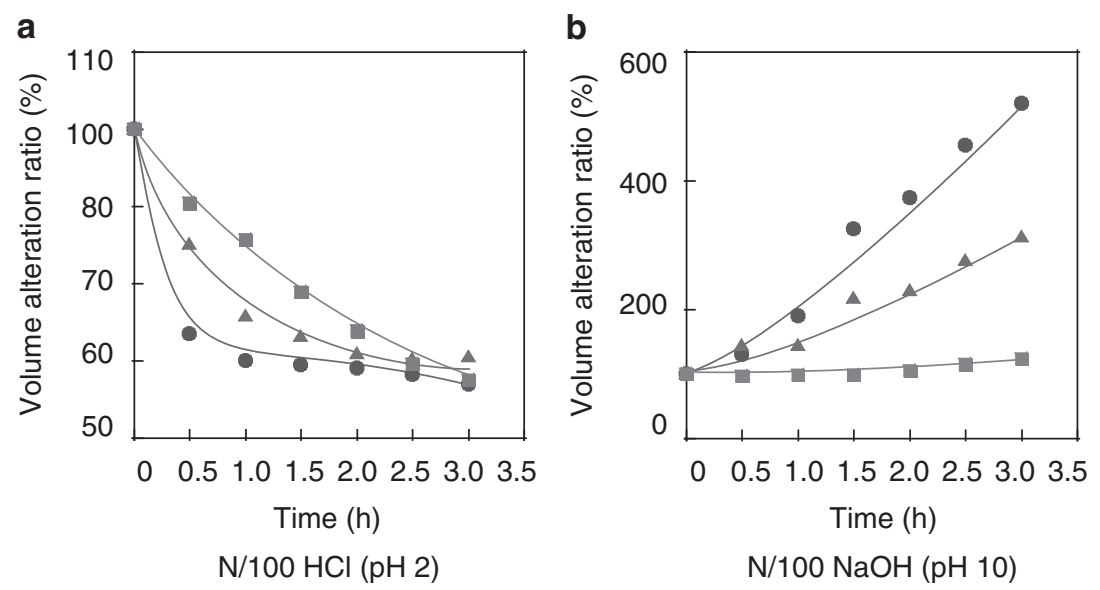

Figure 3 Volume alteration ratio of composite gels with time due to $\mathrm{pH}$. The gels immersed in (a) $\mathrm{pH} 2$ and (b) $\mathrm{pH} 10$ solutions. Closed squares indicate $1000 \mathrm{~mm} \mathrm{CaCl} 2-480 \mathrm{~mm}\left(\mathrm{NH}_{4}\right)_{2} \mathrm{HPO}_{4} 1 \%$ alginate gels; closed triangles, $250 \mathrm{~mm} \mathrm{CaCl} 2-120 \mathrm{~mm}\left(\mathrm{NH}_{4}\right)_{2} \mathrm{HPO}_{4} 1 \%$ alginate gels; closed circles, $1 \%$ alginate gels.

The change in shape of the gels attributed to $\mathrm{pH}$ was interpreted as follows (Figure 5).

In acidic solution, $\mathrm{COO}^{-}$ions and $\mathrm{H}^{+}$ions bonded in the presence of a large quantity of $\mathrm{H}^{+}$ions, and then the gel contracted because of the neutralized electrostatic repulsion. ${ }^{26,27}$ In the alkaline solution, $\mathrm{COO}^{-}$ions and $\mathrm{H}^{+}$ions were dissociated, and then the gel swelled because of $\mathrm{H}^{+}$ion diffusion and electrostatic repulsion. ${ }^{25,26}$ The shape change of the gel was caused by the electrostatic repulsion between carboxylate anions in the hydrogels.

Furthermore, the shrinkage and swelling of the gel was inhibited by the presence of hydroxyapatite. The solubility of hydroxyapatite is also $\mathrm{pH}$ responsive. Hydroxyapatite is soluble at lower $\mathrm{pH}$ and insoluble at higher $\mathrm{pH}^{28,29}$ It is suggested that the composite gel containing hydroxyapatite decreased in size as much as the alginate gel in $\mathrm{HCl}$ solution did, and the composite gel did not increase much in size in the $\mathrm{NaOH}$ solution. In the process of absorption of hydroxyapatite in vivo, hydroxyapatite must be dissolved. It is estimated that this composite gel is functional with high resolvability and high absorbance in vivo.

Observation of the electrochemical properties of the composite gels Figure 6 shows photographs of the composite gels before and after applying voltage for an hour. In distilled water, the calcium alginate gels near the cathode increased in volume with applied voltage. Conversely, the hydroxyapatite/calcium alginate composite gels

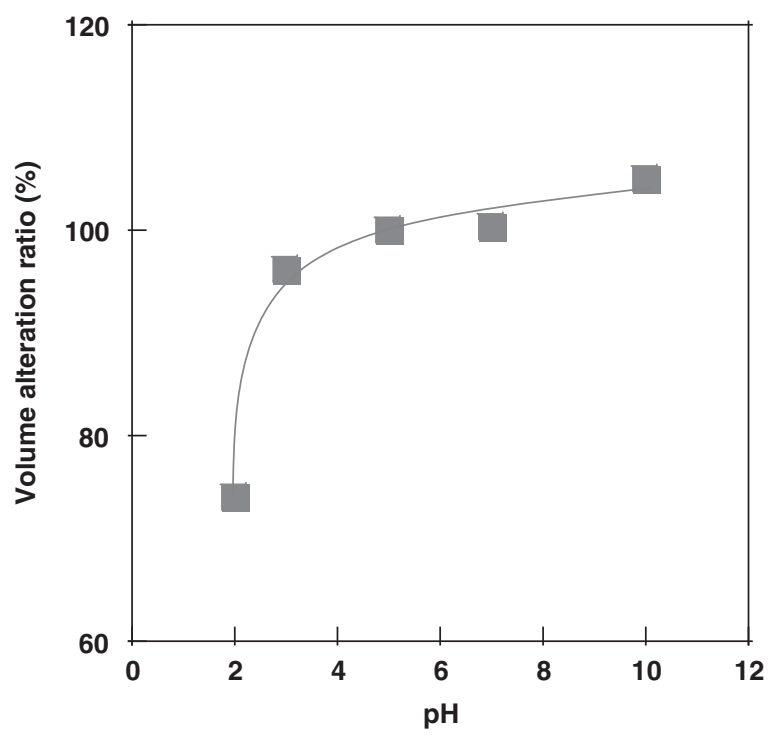

Figure $4 \mathrm{pH}$ dependence of $1000 \mathrm{~mm} \quad \mathrm{CaCl}_{2}-480 \mathrm{~mm} \quad\left(\mathrm{NH}_{4}\right)_{2} \mathrm{HPO}_{4} \quad 1 \%$ alginate gel after immersion for $2 \mathrm{~h}$.

decreased in size with applied voltage. The calcium alginate gels became larger and the composite gels became smaller with a high applied voltage. 
a

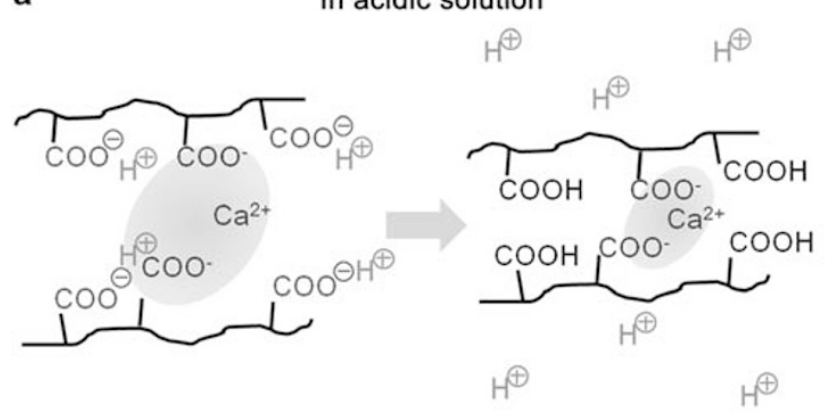

b

In alkaline solution
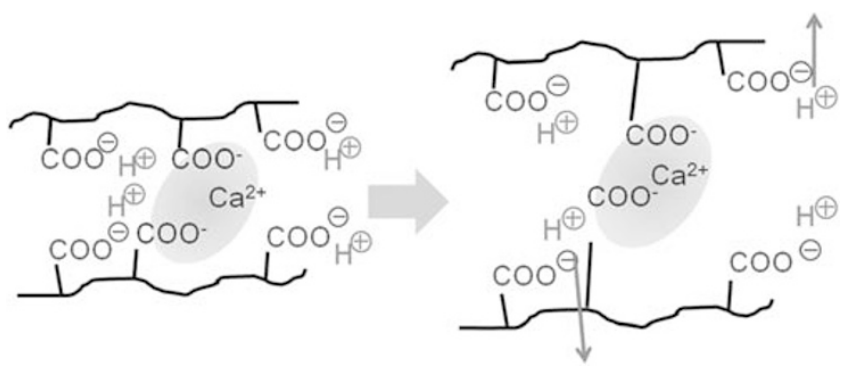

Figure 5 Mechanism of swelling and shrinking due to $\mathrm{pH}$. The gels immersed in (a) acidic solution and (b) alkaline solution.

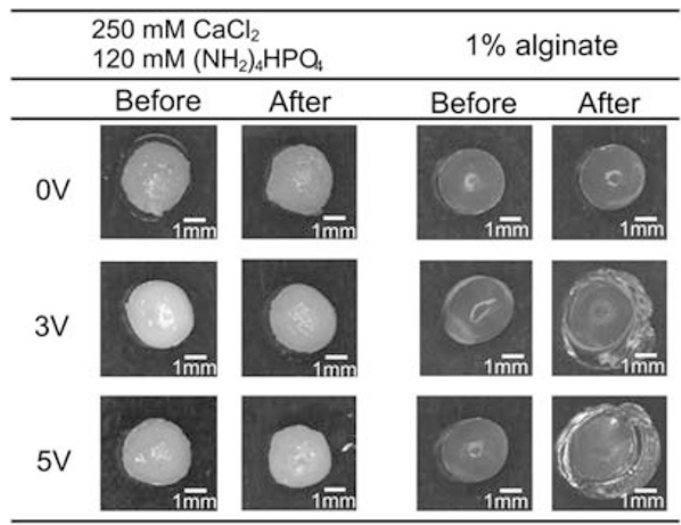

Figure 6 Response of gels to applied voltage.

The shape change of the gels attributed to applied voltage was interpreted as follows (Figure 7). In the case of calcium alginate gels, the $\mathrm{Ca}^{2+}$ ions, which were used for cross-linking, and $\mathrm{H}_{3} \mathrm{O}^{+}$ions, which were generated in the alginate gels, moved toward the cathode, ${ }^{26,27,30}$ and the water from the outside entered into the alginate gels. Therefore, the calcium alginate gel near the anode decreased in size, and the calcium alginate gel near the cathode increased in size. Figure 8 shows a side view of the $250 \mathrm{~mm} \mathrm{CaCl} 2-120 \mathrm{~mm}\left(\mathrm{NH}_{4}\right)_{2} \mathrm{HPO}_{4}$ $1 \%$ alginate gel after applying voltage. The top of the gel was in contact with the cathode, and the bottom of the gel was in contact with the anode. In the case of composite gels, there is a large amount of hydroxyapatite. $\mathrm{Ca}^{2+}$ ions, which were part of the hydroxyapatite, also moved toward the cathode. In addition, $\mathrm{H}_{3} \mathrm{O}^{+}$ions were generated in the composite gels. Therefore, the composite gels decreased in size because of the movement of $\mathrm{H}_{3} \mathrm{O}^{+}$ions. The shrinkage of the hydrogels under applied voltage was due to electroosmosis and electrophoresis. ${ }^{26,27,30}$ a
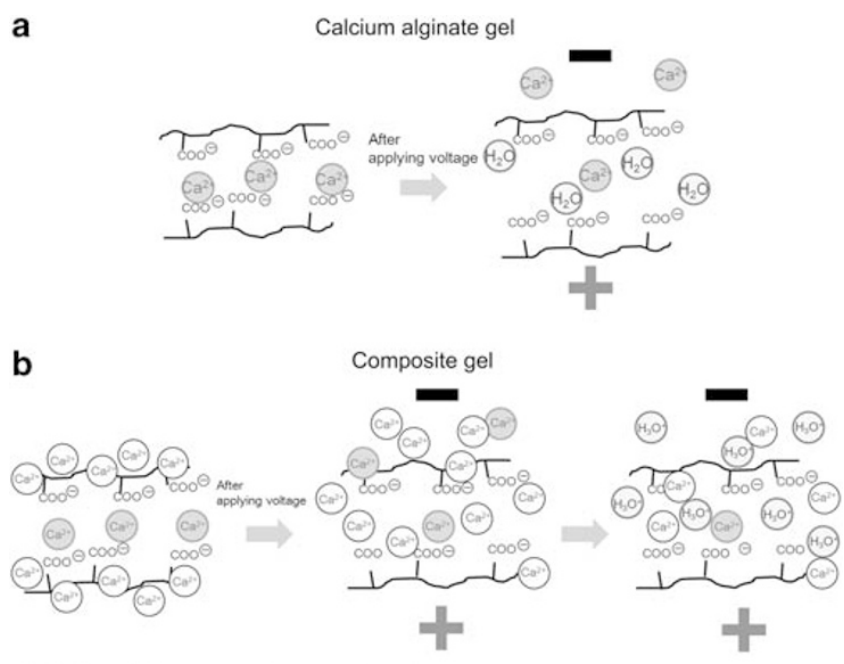

As calcium of using crosslinking

As from Hydroxyapatite $\mathrm{Ca}_{10}\left(\mathrm{PO}_{4}\right)_{6}(\mathrm{OH})_{2}$

Figure 7 Mechanism of swelling and shrinking by electric stimuli.

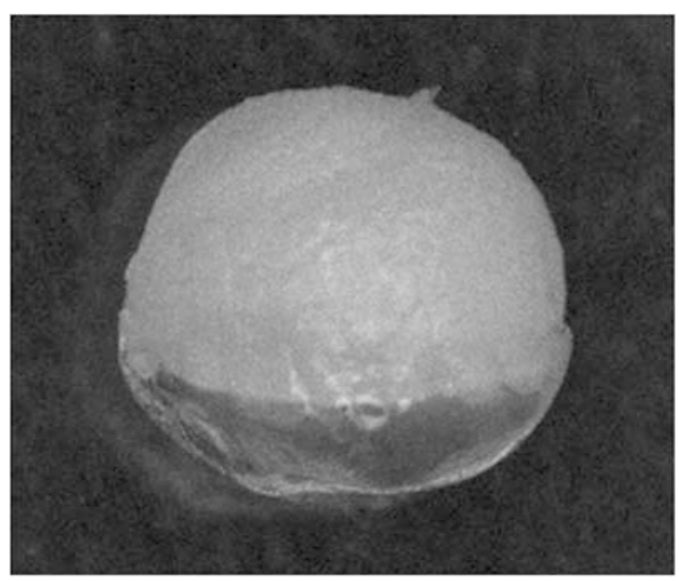

Figure 8 Side view of $250 \mathrm{~mm} \mathrm{CaCl} 2-120 \mathrm{~mm}\left(\mathrm{NH}_{4}\right)_{2} \mathrm{HPO}_{4} 1 \%$ alginate gel after applying voltage for an hour.

In the case of using the $100 \mathrm{~mm} \mathrm{CaCl}_{2}$ solution instead of distilled water, Figure 9 shows the volume alteration ratio of the composite gels with electrical stimulus over time. The volume of the gels before applying the voltage was defined as $100 \%$, and the volume alteration ratio of composite gels after applying the voltage was calculated. All of the gels decreased in size with voltage over time. The calcium alginate gels decreased by about $5 \%$ at $5 \mathrm{~V}$ after $5 \mathrm{~min}$. The variation of the composite gels was less than that of the calcium alginate gels. The composite gels that contained a large amount of hydroxyapatite decreased in size less than the gels that contained a small amount of hydroxyapatite.

\section{Observation of the $\mathrm{pH}$ dependence of the composite gels} due to electrical stimulus

The $\mathrm{pH}$ indicator solution produced was dark green and changed color in solutions of various $\mathrm{pH}$. The color was red at $\mathrm{pH} 4$, orange at $\mathrm{pH} 5$, yellow at $\mathrm{pH} 6$, green at $\mathrm{pH} 7$, blue at $\mathrm{pH} 8$, indigo blue at $\mathrm{pH} 9$ and violet at $\mathrm{pH} 10$. 


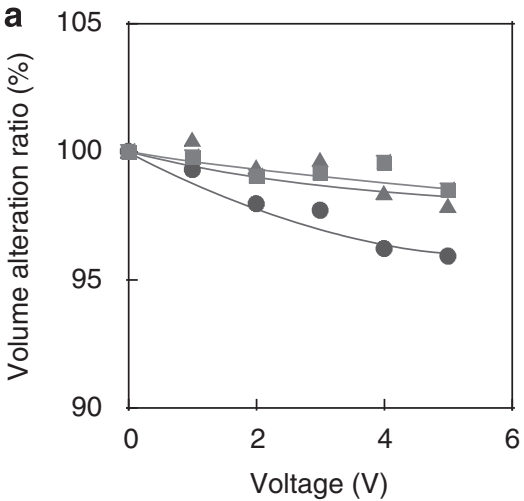

Fixed at 5minutes.

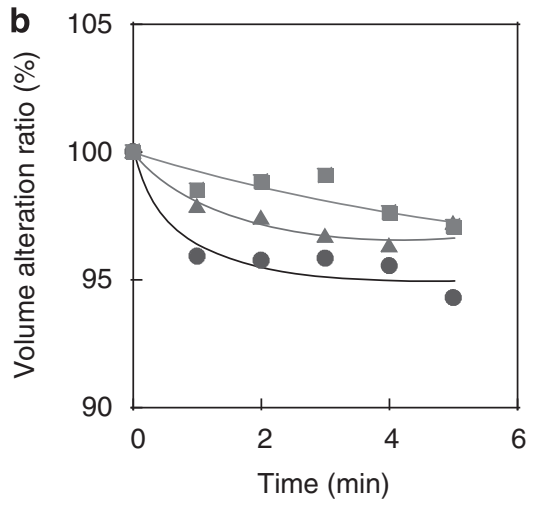

Fixed at $5 \mathrm{~V}$.

Figure 9 Volume alteration ratio of composite gels with applied voltage. The voltage was applied (a) for 5 min and (b) at $5 \mathrm{~V}$. Closed squares indicate $1000 \mathrm{~mm} \mathrm{CaCl} 2-480 \mathrm{~mm}\left(\mathrm{NH}_{4}\right)_{2} \mathrm{HPO}_{4} 1 \%$ alginate gels; closed triangles, $250 \mathrm{~mm} \mathrm{CaCl} 2-120 \mathrm{~mm}\left(\mathrm{NH}_{4}\right)_{2} \mathrm{HPO}_{4} 1 \%$ alginate gels; closed circles, $1 \%$ alginate gels.

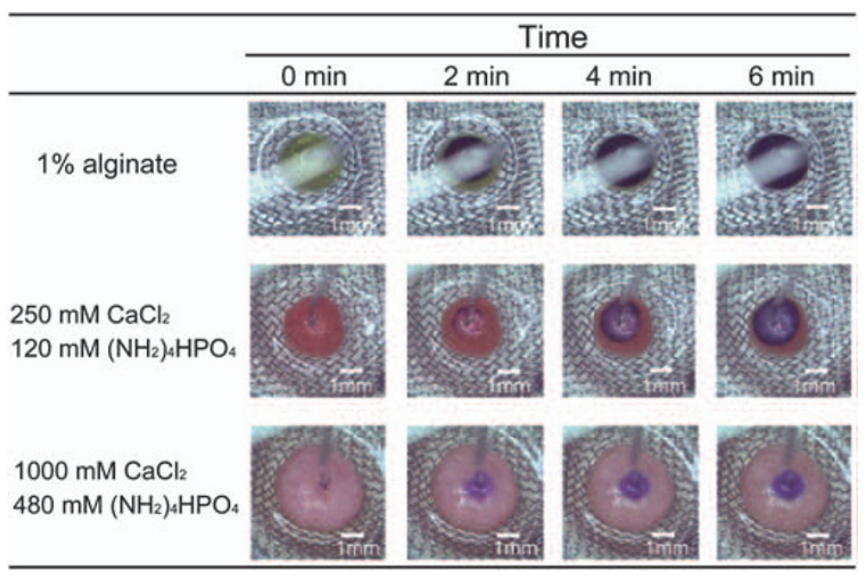

Figure 10 Color alteration of composite gels containing $\mathrm{pH}$ indicator with time.

The composite gels and calcium alginate gels were immersed in a $\mathrm{pH}$ indicator solution. The composite gels were red, and the calcium alginate gels were green in the $\mathrm{pH}$ indicator solution. The color of all gels containing the $\mathrm{pH}$ indicator solution changed with the applied voltage (Figure 10).

The calcium alginate gels began to change from green to purple within a 2-min period. The majority of the gel changed to purple within $6 \mathrm{~min}$. Conversely, the composite gels began to change from red to purple within $2 \mathrm{~min}$, and the purple-colored area expanded with applied voltage over time. The gel containing a large amount of hydroxyapatite changed color more slowly than did the gels without hydroxyapatite. The content of hydroxyapatite was related to the color change of the gels. It is considered that the amount of charged electrolyte in the composite gels decreased with the amount of hydroxyapatite because ionic bonds were formed between the calcium and polyelectrolyte. As a result, the ions were not readily transported within the composite gels containing large amounts of hydroxyapatite.

In addition, the portion of gels in contact with the anode indicated alkalinity by turning a purple color. This occurred by removing the $\mathrm{H}_{3} \mathrm{O}^{+}$in the gels attributed to the applied voltage. It is assumed that the stretching behavior was related to the movement of ions; therefore, the $\mathrm{pH}$ of the gels changed because of the applied voltage.

\section{CONCLUSION}

A hydroxyapatite/calcium alginate composite gel was synthesized in one step from $\left(\mathrm{NH}_{4}\right)_{2} \mathrm{HPO}_{4}$-sodium alginate solution and $\mathrm{CaCl}_{2}$ solution. The change in volume of the composite gels was related to the $\mathrm{pH}$ and applied voltage. In the case of $\mathrm{pH}$, the change in volume of the composite gels and calcium alginate gels was dependent on the dissociation of carboxylate anions with the environmental solution. In the case of electrical stimulus, the change in volume of the composite gels and calcium alginate gels depended on the movement of dissociated carboxylate anions because of the applied voltage. In addition, the stretching behavior of the composite gels depended on the content of hydroxyapatite. These composite gels were shown to have good bone-filling and drug release properties.

1 Kajiwara, K. \& Ross-Murphy, S. B. Synthetic gels on the move. Nature 355, 208 (1992).

2 Osada, Y., Okuzaki, H. \& Hori, H. A polymer gel with electrically driven motility. Nature 355, 242 (1992).

3 Gong, J. P., Nitta, T. \& Osada, Y. Electrokinetic modeling of the contractile phenomena of polyelectrolyte gels. One-dimensional capillary model. J. Phys. Chem. 98, 9583 (1994).

4 El-Mohdy, H. L. A. \& Safrany, A. Preparation of fast response superabsorbent hydrogels by radiation polymerization and crosslinking of $\mathrm{N}$-isopropylacrylamide in solution. $\mathrm{Rad}$. Phys. Chem. 77, 273 (2008).

5 Dentini, M., Rinaldi, G., Barbetta, A., Risica, D., Anselmi, C. \& Skjåk-Bræk, G. Ionic gel formation of a (pseudo)alginate characterised by an alternating MG sequence produced by epimerising mannuronan with AlgE4. Carbohydrate Polym. 67, 465 (2007).

6 Hoad, C., Rayment, P., Cox, E., Wright, P., Butler, M., Spiller, R. \& Gowland, P. Investigation of alginate beads for gastro-intestinal functionality, Part 2: In vivo characterization. Food Hydrocolloids 23, 833 (2009).

7 Skjåk-Bræk, G., Grasdalen, H. \& Smidsrød, O. Inhomogeneous polysaccharide ionic gels. Carbohydrate Polym. 10, 31 (1989).

8 Lee, M., Lo, A. C., Cheung, P. T., Wong, D. \& Chan, B. P. Drug carrier systems based on collagen-alginate composite structures for improving the performance of GDNF-secreting HEK293 cells. Biomaterials 30, 1214 (2009).

9 de Martimprey, H., Vauthier, C., Malvy, C. \& Couvreur, P. Polymer nanocarriers for the delivery of small fragments of nucleic acids: oligonucleotides and siRNA. Eur. J. Pharm. Biopharm. 71, 490 (2009).

10 Straatmann, A. \& Borchard, W. Phase separation in calcium alginate gels. Eur. Biophys. J. 32, 412 (2003).

11 Decho, A. W. Imaging an alginate polymer gel matrix using atomic force microscopy. Carbohydrate Res. 315, 330 (1999).

12 Liu, X. D., Yu, W. Y., Zhang, Y., Xue, W. M., Yu, W. T., Xiong, Y., Ma, X. J., Chen, Y. \& Yuan, Q. Characterization of structure and diffusion behaviour of $\mathrm{Ca}$-alginate beads prepared with external or internal calcium sources. J. Microencapsulation 19, 775 (2002).

13 Iwatsubo, T., Sumaru, K., Kanamori, T., Shinbo, T. \& Yamaguchi, T. Construction of a new artificial biomineralization system. Biomacromolecules 7, 95 (2006). 
14 Holmes, R. E., Bucholz, R. W. \& Mooney, V. Porous hydroxyapatite as a bone-graft substitute in metaphyseal defects. A histometric study. J. Bone Joint Surg. 68A, 904 (1986).

15 Ishihara, K., Arai, J., Nakabayashi, N., Morita, S. \& Furuya, K. Adhesive bone cement containing hydroxyapatite particle as bone compatible filler. J. Biomed. Mater. Res. 26, 937 (1992).

16 Tamai, N., Myoui, A., Tomita, T., Nakase, T., Tanaka, J., Ochi, T. \& Yoshikawa, H. Novel hydroxyapatite ceramics with an interconnective porous structure exhibit superior osteoconduction in vivo. J. Biome. Mater. Res. 59, 110 (2002).

17 Penninger, C. L., Patel, N. M., Niebur, G. L., Tovar, A. \& Renaud, J. E. A fully anisotropic hierarchical hybrid cellular automaton algorithm to simulate bone remodeling. Mech. Res. Comm. 35, 32 (2008).

18 Sims, N. A. \& Gooi, J. H. Bone remodeling: multiple cellular interactions required for coupling of bone formation and resorption. Semin. Cell. Dev. Biol. 19, 444 (2008).

19 Pivonka, P., Zimak, J., Smith, D. W., Gardiner, B. S., Dunstan, C. R., Sims, N. A., Martin, T.J. \& Mundy, G.R. Model structure and control of bone remodeling: a theoretical study. Bone 43, 249 (2008).

20 Sakai, H. \& Kuno, M. Ion signaling mechanisms in bone remodeling. Igaku no Ayumi 199, 199 (2001).

21 Ozawa, H., Ejiri, S. \& Nakamura, H. Cell biological aspects on bone resorption. Tanp. Kaku. Koso. 40, 492 (1995).
22 Yamada, S. Indicator for concentration of hydrogen ion. Chem. Abstr. 28, 2258 (1934)Japanese Patent 99, 664, 21 February (1993).

23 Laurence, S. F. \& Gruntfest, I. J. Demonstration experiments using universal indicators. J. Chem. Educ. 14, 274 (1937).

24 Taguchi, T., Kishida, A. \& Akashi, M. Hydroxyapatite formation on/in poly(vinyl alcohol) hydrogel matrices using a novel alternate soaking process. Chem. Lett. 27, 711 (1998).

25 Obara, S., Saito, H., Yamauchi, T. \& Tsubokawa, N. Preparation of hydroxyapatite/ calcium alginate composite gel and application to medical material In: SAMPE 2008, Technical Conference Proceedings: Material and Process Innovations: Changing our World; 18-22 May 2008; Long Beach, CA, USA. Society for the Advancement of Material and Process Engineering, Covina, CA, USA; CD-ROM-7pp.

26 Qiu, Y. \& Park, K. Environment-sensitive hydrogels for drug delivery. Adv. Drug Deliv. Rev. 53, 321 (2001).

27 Gutowska, A., Bark, J.S., Kwon, I. C., Bae, U. H., Cha, Y. \& Kim, S. W. Squeezing hydrogels for controlled oral drug delivery. J. Controlled Release 48, 141 (1997).

28 Okazaki, M. 'Chemistry of Apatites', Tokai University, Kanagawa, Japan (1992).

29 Nonami, T., Funakoshi, K., Hase, H. \& Tone, K. Application of apatite cated titanium dioxide. J. Surface Finish. Soc. Jpn. 55, 335 (2004).

30 Sawahata, K., Hara, M., Yasunaga, H. \& Osada, Y. Electrically controlled drug delivery system using polyelectrolyte gels. J. Controlled Release 14, 253 (1990). 